\title{
The Revitalization of Tari Buku Nias Utara as a Teaching Material of Appreciation for Nias Dance Techniques Subject
}

\author{
Tuti Rahayu', Sitti Rahmah', Iskandar Muda ${ }^{3}$ \\ ${ }^{1,2,3}$ Universitas Negeri Medan, Indonesia \\ tutirahayu12@gmail.com
}

\begin{abstract}
The purpose of this research is to revitalize Tari Buku from Nias Utara area which is almost extinct and to re-present it as a performance and its development in the Muslim community in Lahewa Nias Utara. From this revitalization process emerged the development results in the form of history, functions, make-up and clothing for Tari Buku and the local culture of Nias Utara. The method used is the R\&D methodology. The location of this research was conducted in Lahewa sub-district, North Nias district. Data collection techniques through observation, in-depth interviews and documentation. The data that has been collected, and then analyzed using a qualitative paradigm with a project based research method, which is obtained through data reduction, data testing and drawing conclusions. The data validity test used the source triangulation model and the triangulation technique. The results of the development are used in learning the Nias dance technique subject to Dance Education students at Universitas Negeri Medan.
\end{abstract}

Keywords revitalization; tari buku; identity strengthening

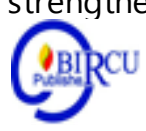

\section{Introduction}

Efforts to preserve local culture through learning resources in education are to provide students with an understanding of local cultural outcomes. Sustainability is marked by cultural heritage and character belonging to the community and nation. Therefore, education is a process of cultural heritage and national character of the young generation as well as a process of developing its culture. Tradition can also be seen as a hereditary habit from a society with a long tradition that can include all complex forms of life, so that it is not easily put aside and treated the same or the same, because tradition is not a subject of the dead, but a living tool to serve human life (Rendra, 1983: 3).

Education is one of the most important places to preserve the existence of traditional arts. The transfer of traditional arts from one party to another, one generation to the next, carried out either by individuals or groups, by formal institutions and informants (Supanggah, 2002: 1). The learning process is usually called cultural socialization. Activities can be carried out through formal or non-formal schools. To understand properly, learning must develop a reliable method of interaction with the environment based on his identity (Mulyanto, 2016: 16).

Identity is a style as a characteristic of a certain art which has an important role in the depth of imaging the noble values and identity either individually, in groups or in an area based on the traditions and culture that raised it. Because style in art is an expression of the artist's logical ideology through the intrinsic, taste, intention, power and talent and creativity that is owned, visualized and actualized into a beautiful original form and reflects an alluring characteristic and identity. 


\section{Review of Literatures}

Besides specifically, there is also a dance style that is individualized as a personal identity. Each of these styles has a very interesting and unique existence and has its own charm, weight and predicate so that it becomes an aspect of local cultural identity as a differentiator from other local cultures. Local culture as an identity in a wider scope is an aspect that distinguishes a nation from another nation. Our mainstream culture was centered around the partnership model but following a period of chaos and cultural disruption, there was a fundamental shift towards the dominator model. The greater archaeological data which are available on ancient civilizations made it possible to document this shift in more details through the analysis of prehistoric cultural evolution (Eisler in Nurwani 2020).It becomes a differentiator or national identity which ultimately forms a harmony when it is aligned with other nations (Jaeni, 2005: 17). With regard to efforts to preserve local culture in the field of education and also the role of the curriculum, the role of an educator cannot be separated from the role of an educator as a concept in the curriculum for students.

For this reason, it is necessary to develop teaching materials that aim to apply the local culture of North Nias. The local culture is the Tari Buku or the kerchief dance which is now rarely performed in the Lahewa community in North Nias. Tari Buku is an art that is performed at Mamedadaö night, an art night event at wedding parties. This art night event is held at the bride's house. The bridegroom comes to the bride's house.

Tari Buku is very important to be revitalized considering that so far this dance has been marginalized and is rarely performed because at the time of the wedding party is a person who must have more funds. The purpose of this research is to provide a model of cultural preservation through education to develop new visualizations of local cultural characters in North Nias. Through construction and re-visualizing local cultural characters with a new visual style, and reviving the spirit of young people in North Nias in art and documenting the results in textbooks.

According to Febrianto (2020) dance is an art that explores the beauty of human body movements that move, in harmony with the rhythm of music, rhythmic and soulful or can give meaning. Dance is the beauty of the forms of human limbs that move, in rhythm and in harmony. Dance, as one form of art is inseparable from the context of the problem of art in the community. Traditional dance is the work of human creation and inventiveness which is passed on from one generation to the next. In traditional community life patterns, art shows the meaning of oneness or integration with its environment. The integration is manifested through the values of art as a binder of solidarity between citizens of their communities. In this context, traditional arts with various forms and motives, can not be seen as a part that is separated from the supporting community,

Adlin (2020) states that a traditional dance style does not remain in shape. He will always change when taught by the previous generation to the next generation, because the form of dance that is inherited must be interpreted. Traditional dance will continue to be preserved if there is continuous renewal and development by its supporters. Development and renewal can be done by individuals or groups, either in the form of internal perceptions or external perceptions. he peculiarity of dance style is not only influenced by its geographical location but also by the cultural system, patterns of daily activities, as well as the orientation of the cultural values of the supporting communities (Sedyawati in Nugrahaningsih, 2020). 


\section{Research Method}

How to preserve cultural models through education to develop art and cultural teaching materials that can contribute ideas and be creative. How to innovate new forms of performance on local cultural characters that will be used to be delivered in the Nias Dance Technique course. The selection of teaching materials cannot be done at will, because teaching materials also require the use of certain guidelines and principles in the selection of these teaching materials.

By understanding the principles or the steps for selecting teaching materials, it becomes easy to identify the right teaching materials for the learning activities to be carried out. As it is understood that each type of teaching material has advantages and disadvantages. Therefore, if you want to develop and use one particular type of teaching material in the extreme, the combination or integration of various types of teaching materials is better in an extreme. The combination or integration of various types of teaching materials is getting stronger in the choice of teaching materials.

\section{Discussion}

\subsection{History and Development of Tari Buku}

Tari Buku is a Nias dance originating from the northern part of Lahewa, to be precise, North Nias district. The history of this dance book is inseparable from the civilization of the entry of immigrants from Minangkabau to Nias and then this dance was introduced by the immigrant community to the local community,so that the culture has assimilated. There is no single history that can explain in detail the origin of this dance, only a verbal history that is passed down from one generation to the next. The Tari Buku itself is thought to have appeared in the early 20th century and developed during the war for independence.

Based on an interview in 2019, in Lahewa Nias Utara Mr. Siarfan Rainang, 63 years old, said that The actual dance is the Saputangan dance, but in its development time the Saputangan dance becomes a Tari Buku.The book in Nias means bowing, so the Nias people call this dance "Tari Buku" because at that time the dance was performed by the body having to bend down. In the view of the Muslim community in North Nias, bowing is a form of respect and courtesy to fellow citizens. This dance is only danced by men in accordance with customs and traditions, even though it has been running this dance still survives in accordance with the customary and traditional provisions that only a pair of men can dance this and for women it is not allowed to dance. Dancers are not limited to the number of times they are dancing.

Regardless of its origins and historical value, this Tari Buku is a dance that builds up about the tenacity and hard work of the people of North Nias in doing their jobs. From this phenomenon, it can be seen from the movements that are already skilled in dancing through the twists of a handkerchief, which indicate difficulties in navigating life. Often in the show, this dance features various attractions that show off their expertise in rotating the handkerchief movement.

\subsection{Tari Buku}

The various movements in this dance are movements created by the Minangkabau people. As the name suggests, this dance uses a handkerchief from beginning to end. This dance describes the habits of the community, for example in activities after harvesting. 
This activity is full of kinship and has a high spirit of mutual cooperation. The wisdom values and habits of the Nias people are reflected in the movements in this dance variety.

Tari Buku is an imaginative statement of a dance stylist which is expressed through the unity of symbols through movement, energy, space and time. Symbols in art are symbols that have separate meanings and cannot be separated from the values of their cultural background. Tari Buku movement originates from nature and is never separated from people's daily activities. Tari Buku is also a traditional dance influenced by the Minang migrant community.

Tari Buku is a Saputangan dance, where two adult males wear the property of a handkerchief. With an even number which has a meaning about the nature of a solid balance of good and bad balance, left and right, going back and forth. The Saputangan dance is medium tempo, which is $2 / 4$ but is a little faster.

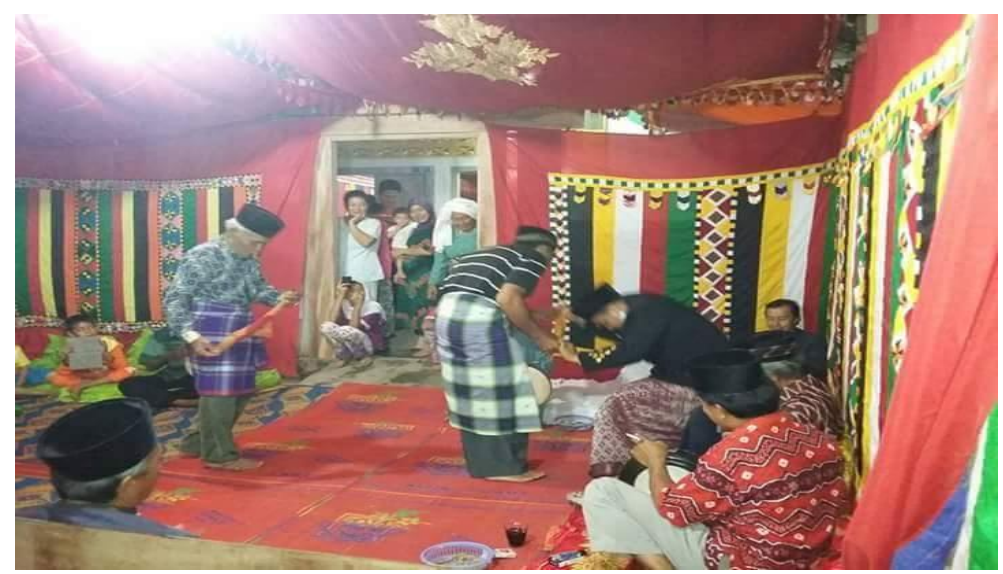

Figure 1. Tari Buku (Handkerchief)

Source: Risty Ratna Dewi Tanjung, 2016

The various movements in this dance are movements created by the Minangkabau people. As the name suggests, this dance uses a handkerchief from beginning to end. This dance describes the habits of the community, for example in activities after harvesting. This activity is full of kinship and has a high spirit of mutual cooperation. The wisdom values and habits of the Nias people are reflected in the movements in this dance variety.

\subsection{Mame dadaö Night}

Mamedadaö night is one of the cultural traditions from North Nias to be precise in the village of Lahewa which still exists today. Mamedadaö night is an art night when it starts. The people of Lahewa North Nias call it Mamedadaö night according to their local language and traditions. Likewise, in some areas, there is a night of mercy, but it returns to their respective customs and traditions because each region must have different traditions and procedures.

The night startsis the last night for the bride-to-be to feel the freedom as a single woman. Literally, apply or use henna, which is to attach the fine collision of the leaves nail girlfriend (Lawsonia inermis) or called henna leaves to the finger nails of the prospective bride. If left on overnight, the fine henna leaves will leave a brilliant red color mark on the nails. The red color on the nails indicates that the woman is married.

So at the Mamedadaö night ceremony for the people of Lahewa North Nias not only had an idea but there was also a dance performance that was performed at Mamedadaö night in the North Nias community of Lahewa as a complement to the event, namely 
singing (playing music and lyrics) as accompaniment to the Tari Buku and other dances. Usually the people of Lahewa hold the Mamedadaö night during weddings, which is where the event is held at night until dawn before the wedding takes place. On the night of Mamedadaö the groom stays at the bride's house all night to participate in dancing with the youth and the local community, while the bride is in the room and is not allowed to go out.

Like the sound of drums and being beaten continuously, this indicates that an artistic event will begin. Music for them is to express themselves, because through music, they can actualize their potential by expressing their feelings, thoughts, ideas and ideals about themselves, society, to God, and to the world.On the night Mamedadaö starts with the Kapri song to accompany the Tari Buku which starts at 21.00 to 22.00. The Kapri song and the Tari Buku are the opening songs for the Mamedadaö evening program. This song and dance depicts a story of interaction among young people in the coastal area and its surroundings, including in North Nias, in tying kinship between one another so that there is unity among coastal communities and open to one another.

The following is the Kapri song:

Elok-elok taga kamana, Daga badagia dilantai papan

Dekapo-apo siamang mati, Makkan buah simanggi hutan

Kalo ada kaca dipintu, Pandan disawah ambo rabakan

Kalo ada karo baitu, Badan jonyawo ambo sarakan

Pisang amebau balawi, Masak sabua di dalam peti

Utang ame dapek dibai, Utang budi dibawo mati

Bagus-bagus tegak menari

Meaning:

Then the board floor rang, why did the gibbon die

Because eating forest simanggi fruit, if there is a glass at the door

Pandanus I lay down on the ground, if there is a word like that

Body and life I surrendered, the golden banana was brought to sail

Cook a seed in a chest, Gold debt can be paid,

Debt is taken to death

Then the Kapulau Pinang song continues to accompany the Folo Fina dance starting at 23.00 to 24.00 which is the essence of a ceremony. This song depicts a story of a husband and wife who have just gotten married, one day when the husband is about to leave his wife to go to earn a living to a country across Malaysia. Her husband sailed on a small boat carrying merchandise from Nias Island.

When holding a wedding ceremony, all people in Lahewa Nias Utara may use Mamedadä̈ night art as a complement to the event. The Mamedadaö night was divided into two, namely; (1) full adat (Ale) is a traditional ceremony complete with chanting and free from rhymes as well as dances, namely the Tari Buku, Sariduni dance and Pulau Pinang. (2) Incomplete adat is a traditional ceremony that holds the Mamedadä night but the dance is not performed, only the chanting is performed.

\subsection{Tari Buku Functions}

All activities carried out by humans are to fulfill their needs in life, such as studying, working, playing and making art. The functions of dance in human life include: (1) for ceremonial purposes, (2) for entertainment, (3) as a performing art, and (4) as a medium for education (Jazuli, 1994: 43). The function of dance as entertainment is a form of dance 
creation intended only to be watched. Tari Buku is known to the public as an entertainment for other popular events such as the Mamedadaö night at weddings. Dance as a means of community communication. Danced with the aim of building togetherness between individuals, and also groups of young and old people. Expressions of joy can be seen from light movements in a dance and movements that are easy to follow.

Based on the information obtained from the sources, the movements in dance contain many meanings. Because the purpose of this dance is to express joy and togetherness which can be seen from the movements that are more in accordance with the songs sung. The entertaining element of this dance is also seen in the contents of the rhymes and the meanings that are implied in the chanted rhymes. The songs sung interpret more about the life of the bride and groom and about the implicit love for her partner. However, at this time, the songs that were sung were usually the existing ones, and the ones the singer had memorized. The meanings of these rhymes have several differences, some are full of moral messages, some contain the contents of the heart and love, there are also jokes that often make the audience laugh, one of them. An example of the rhyme reads.

\section{Ado Api diambang gunung, anak buaya lape, Niat ati mamaluak gunung, apo dayo tangan tak sampai Layang-layang di pulo batu, tebayang lalu pulo Aso Raso buli pinto balaku, mengenang kasih diantaro}

There is a fire on the mountain, the young crocodile is loose The intention to hug the mountain, can the hand not reach it. Kite on Batu Island, you can imagine the island of Aso

\subsection{Preservation Model}

Cultural preservation model is a form, design, pattern of life to preserve an object, event or event that describes the real world. The preservation model is a plan in the form of a design pattern that is used as a guide for preserving cultural values in order to be able to survive, not to experience deviations, and not to be lost by the progress and development of the current culture to be passed on to the next generation. The purpose of this preservation is to maintain, preserve and preserve cultural values from the past to maintain the sacredness of these cultural arts.

One of the cultural preservation is to do cultural revitalization (strengthening). Regarding cultural revitalization, there are three steps taken, namely: 1. Understanding to raise awareness, 2. Collective planning, and 3. Generating cultural creativity (Chedar Alwailah, 2006: 18). Meanwhile, Soekanto (2003: 432) says that sustainability is impossible to stand alone, therefore it is always paired with developments in survival. Sustainability is one aspect of stabilizing human life, while survival is a reflection of dynamics. Becoming a provision in cultural preservation is the existence of a cultural form where the culture that is preserved is still there and known, even though its development is increasingly eroded

By using picture media, VCDs, textbooks, the meaning of a dance term will become clearer. With this advantage, it will be easier for someone to learn Tari Buku. This advantage is also able to motivate to learn Tari Buku, while reading a dictionary of languages from North Nias. Indirectly, this textbook can foster a love for North Nias culture. Love for North Nias culture is a reflection of a positive attitude towards culture, which is the main asset for preserving the Tari Buku as well as North Nias culture. This 
can be understood because the Tari Buku is one of the elements of Nias Utara culture as well as forming Nias Utara culture.

As a community, it must be able to preserve the existence of traditional dance so that it is not lost and is maintained. Do not let Indonesia's dance art be recognized by other countries because we cannot preserve it. However, today's young people are more interested in the emergence of modern popular culture than traditional dance. Therefore, there will be many efforts to preserve traditional dances such as suggesting schools to hold competitions between schools and giving rewards if they win and it will be easy to enter the desired school. using the achievement path, conducting training in traditional dance culture, dance events, courses for dance, teaching traditional dances to children so that they do not lose their culture, participate in cultural preservation and practice it in their daily life.

\subsection{Performance Form}

A work of art has its respective performing art forms. Performances contain the meaning of showing something of artistic value, but always trying to attract attention when watched to become a show. It must be planned and there is a role played and performed on the stage accompanied by music and decorations that add to the beauty of the show (Jazuli, 1994: 60).

Performance form is an arrangement of elements or aspects of an art performance that is shown, seen so that it can be enjoyed and noticed by others. Performing art forms as works of artists, are born as expressions through the elements as mentioned. The form of sound is in the form of music that can be heard by the ear senses, while the form of clothing and make-up can be seen by the sense of sight. The form of the Tari Buku performance from North Nias can be seen through the sequence of performances and the supporting aspects of the show. The main aspects in the form of the North Nias Tari Buku performance are divided into 5, namely (1) Movement (2) Accompaniment (3) Property (4) Make-up and (5) Dressmaking.

\section{a. Motion}

In this Tari Buku, the basic movements are divided into four, namely:

1. Limb Movement

a. Maliwa ba gambera (move left and right)

b. Lafangasa (drag)

c. Fafuta (rotate)

2. Torso Motion:

a. Lafabuku (bent over)

b. Hihandrakö (jump)

3. Arm Motion:

a. Fafutadanga (turning hand)

b. Lafahehea danga (swinging hand)

c. Pronounce (wrapped around)

4. Movement of the Head:

a. Fatugu (down)

b. Falake awo (glancing at the couple)

The range of movements performed in the Tari Buku:

a. Starting Position

b. Intro Entry

c. Body position bent 
d. Body position in opposite direction to partner

e. Rotate each pair left $1 \times 8$ and rotate right $1 \times 8$

f. Switch the position of the foot dragging the right leg while walking and switch positions

g. The position of the body facing the handkerchief is swung left and right

h. Turn the semicircle to the right, then go back to face the partner and return to the full turn to the left, handkerchief straight following the right hand above the right hand.

Table 1. Techniques and Variety of Tari Buku Movements

\begin{tabular}{|c|c|c|}
\hline Body & Information & Motion in Pictures \\
\hline $\begin{array}{l}\text { Technique } \\
\text { Mboto Sara } \\
\text { Lafabuku (bent } \\
\text { over) }\end{array}$ & $\begin{array}{l}\text { Early motion. } \\
\text { Body bent forward }\end{array}$ & \\
\hline $\begin{array}{l}\text { Technique } \\
\text { Mboto Dua } \\
\text { Variety }\end{array}$ & $\begin{array}{l}\text { The body is bent to follow the } \\
\text { direction of the feet in a right } \\
\text { diagonal direction. }\end{array}$ & \\
\hline $\begin{array}{l}\text { Fafuta danga } \\
\text { (turning hand) }\end{array}$ & & \\
\hline $\begin{array}{l}\text { Technique } \\
\text { Mboto Telu } \\
\text { Falake awo } \\
\text { (glancing at the } \\
\text { couple) }\end{array}$ & $\begin{array}{l}\text { The body is bent to follow the } \\
\text { direction of the leg in a diagonal } \\
\text { direction to the right back }\end{array}$ & \\
\hline $\begin{array}{l}\text { Technique } \\
\text { Mboto Efa } \\
\text { Lafahehea danga } \\
\text { (swinging hand) }\end{array}$ & $\begin{array}{l}\text { Body bent to follow the direction of } \\
\text { the feet by pointing forward. And } \\
\text { the body is shocked }\end{array}$ & \\
\hline
\end{tabular}




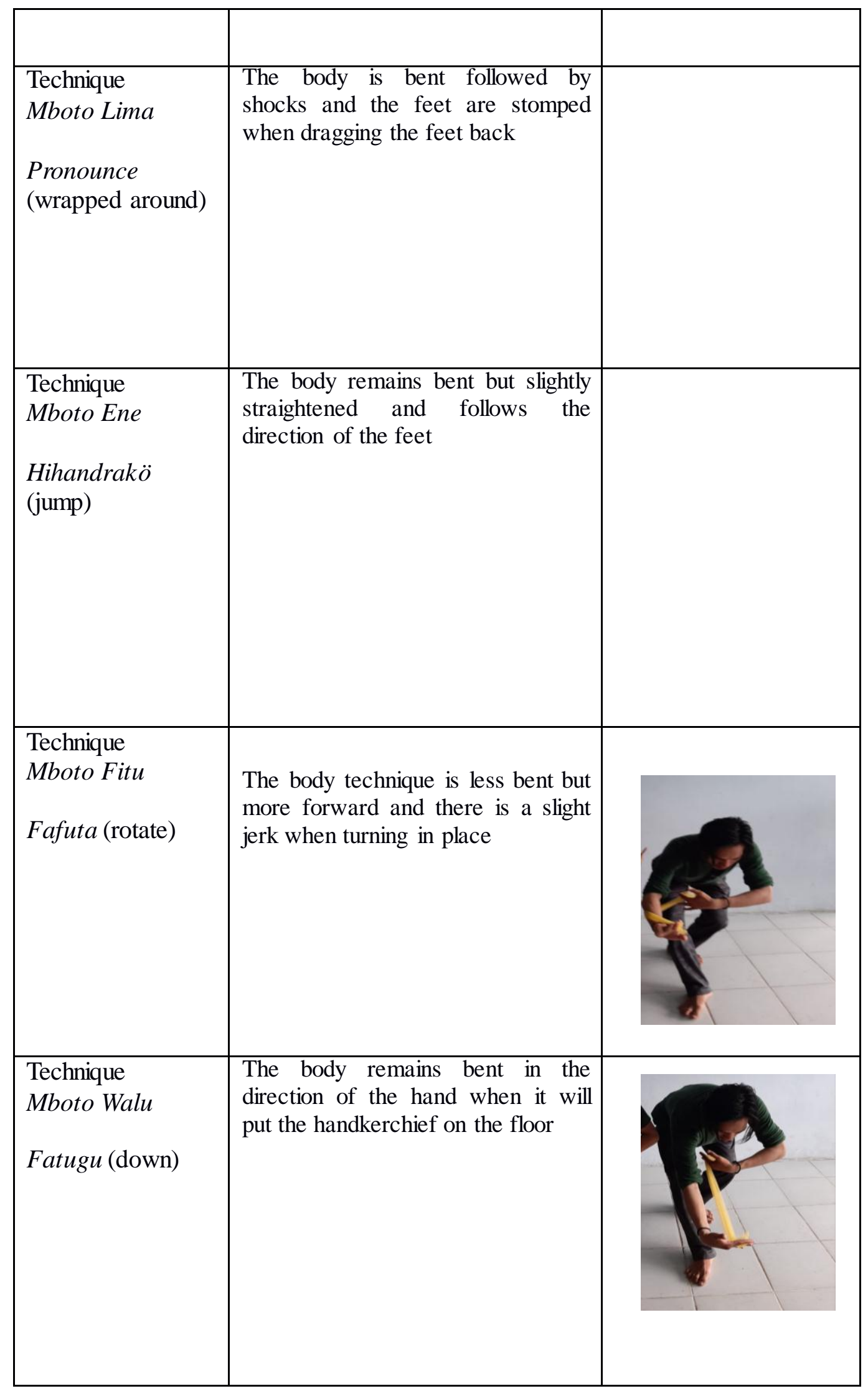




\section{b. Accompaniment}

The song that accompanies the dance in this book is the Kapri song with lyrics. Stick to alt-musical instruments. Musical instruments are a medium that is generally used as an accompaniment to performances. Like the Tari Buku to be performed, it requires a musical instrument to accompany it, This dance is accompanied by traditional musical instruments, namely; violins, drums and rapa'i and accompanied by poetry in the form of poetry which contains cultivation of wisdom and advice. This dance is not limited by the duration of time how fast or how long this music will stop and there is no count of movement because it is moved to the taste of the music that flows. The explanation of the instrument is as follows:

\section{Rapa'i}

Rapa'i is a musical instrument that is played by beating it by hand without using a stick. Rapa'i plays a role in regulating the tempo, rhythm, behavior, jingling and making the atmosphere more lively and lively. Rapa'i is played in a sitting position, the left hand holds the paloh or palong (body) rapa'i, the right hand hits the skin of the rapa'i and when it is hit in the middle it produces a large hum or echo sound, if it is hit on the edge it will get a sharp sound. In this musical game, Rapa'i is very much needed as a dance accompaniment that will complement the accompaniment of the Tari Buku.

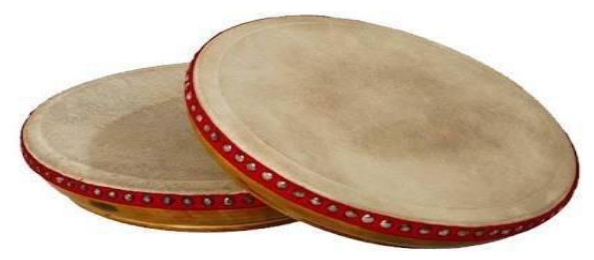

Figure 2. Rapa'i

\section{Drum}

Drum is a musical instrument that is played by beating. Usually played by hand or with a drum bat.Drums are scattered in almost every area of the archipelago. Each region plays drums with distinctive rhythms and beats to accompany traditional dances and traditional songs. The shape of a drum musical instrument is like a tube that shrinks at one end. The diameter of the two sides is different from one another. In general, the shapes that exist in various regions are not much different, but variations occur in the diameter of the drum size, the carved motif on the outside of the drum and animal skin used as a membrane.

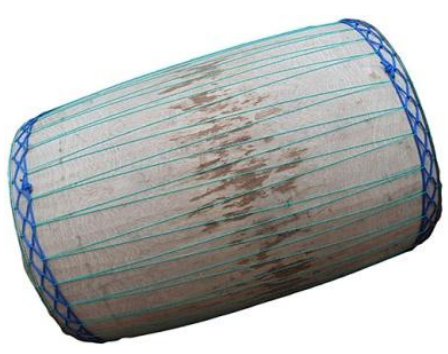

Figure 3. Drum 


\section{Violin}

Violin is a stringed instrument that is played by swiping. The violin is often called a fiddle if it is used to play traditional songs and musical accompaniment in traditional dance. As a characteristic of the music in this dance, a violin is also needed as a musical instrument to accompany the dance to be played together with the rapa'i and drums.

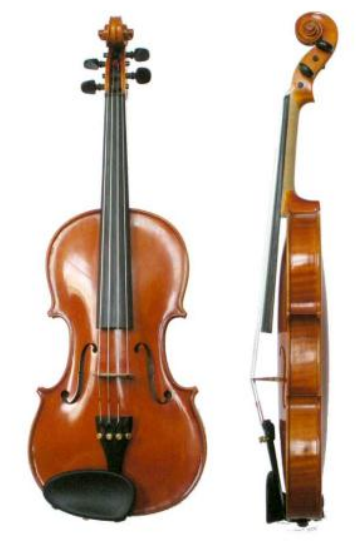

Figure 4. Violin

\section{Poetry}

Poetry is a symbol of the language used by composers to express feelings to make it easier for listeners to digest their musical works. Traditional songs usually use the local language in telling the content of the song. Sometimes the composer repeats the poetry. Repetition of a melody or verse is one way to emphasize the emotions of the song. The poetry in the Tari Buku is in the form of a poem containing advice.

As previously explained, the Explanation Tari Buku from Minangkabau so that the lyrics used as accompaniment to this dance also use the Minangkabau language which is still used today and this Minang language also still exists and is mixed with everyday Nias language. The following are the verses of the Tari Buku:

Aso api dilambang gunuang Anak buayo manyu lapeh Niakhati mamaluak gunuang Apa dayo tangan tak sampai
The hope of fire in the mountain symbol

The young crocodile drifted off

The heart's intention to hug the mountain

Didn't the hands arrive?

Layang-layang di pulau batu

Tabayang lalu pulau aso

Raso jobudi pinto balaku

Menenggang kasiah diantaro 
Ado aso diatas gunuang

Bijak urang tando tak jadi

Niak ingin mamaluak gunung

Apa daya tak sampai
There is hope on the mountain

Wise people sign off

The heart's intention to hug the mountain

Is it power not up

\section{c. Property}

The equipment or equipment played by the dancer on stage is called property. For example, scarves, handkerchiefs, fans, sticks, umbrellas, cloths, hats, and others. Properties are objects used in dance. The properties used must also match the theme or message for the dance. Every dance in each region must have a handkerchief as a property, but the purpose and meaning are different. This Tari Buku uses a handkerchief as a dance supporting property. The meaning of this technique of holding a handkerchief is about the tenacity and hard work of the people of North Nias in doing work.

\section{d. Cosmetic}

Makeup is a form or effort to beautify someone, especially on the face. Make-up in the performing arts is needed to portray the characters on the stage. Make-up is an art to determine the character on the stage, the changes of the dancers on the stage make the atmosphere in accordance with the theme (Harymawan, 1993: 134). As a representation of the characters on stage, or on stage, acting with the players they need is make-up as an effort to arrange decorations for an object to be performed.

The function of make-up is to change personal character, to increase expression, and to increase the attractiveness of the dancer's appearance (Jazuli 2001: 116). Make-up is an aspect that has its own special features from each of the themes of the dance. The makeup used in the Tari Buku aims to emphasize the lines of the eyes. the use of lashes is intended to emphasize the eye line. Using eyelashes is also necessary to show beauty.

\section{e. Dressmaking}

Clothing is part of a show that is very much needed as a complement to these dance elements. Dance clothing is understood as a body covering consisting of items attached to a person's body, including for the benefit of dancing people. But in this dance, the clothes worn are not required to wear fancy dance costumes or clothes, the important thing is that the clothes worn are suitable for use and do not interfere with movement. Usually the people of North Nias wear ordinary clothes when dancing, but if they are required to wear uniforms, they only wear a koko shirt along with a cap and wear a sarong that looks simple and comfortable when used for dancing.

The clothes used for men in the Tari Buku are: White shirt, sarong and cap as a head covering. While in its development the Tari Buku clothes used by women are: Red brackets, black trousers, songket cloth is used as a cover from the waist to the knees and a black hijab for the head cover. 


\section{Conclusion}

\subsection{Revitalization}

Revitalization of traditional arts is part of traditional art conservation efforts. Revitalization is an effort to change a type of tradition that is adapted to the development of society and has a new function without eliminating the artistic spirit. As a cultural wealth and traditional heritage that is of high value, it is a Tari Buku that must be maintained and developed. Several steps must be taken to try to preserve cultural heritage, starting from excavation, inventory and documentation, introduction, development. As a product of local culture, dances from the revitalization of the Buku dance can be used as a way to strengthen the identity of the Lahewa people in the midst of fast-moving changes.

Tari Buku can be used as a symbol of identity and social capital in North Nias. Tari $B u k u$ needs to be revitalized to produce or revive something whose existence is still in use so that it needs to be maintained and developed. There are folk arts that still have and are able to accompany the dynamics of development, which can develop some that do not grow at the pace of community development if there is no change and assistance from other parties.

\subsection{Preservation}

Preservation is something that must be continued, and efforts in preserving it, namely: improving the quality of human resources in advancing traditional culture, providing more motivation to maximize cultural potential, along with empowerment and preservation. Trying to revive the spirit of nationalism, kinship, hospitality and high solidarity, always maintaining Indonesian culture so that it does not become extinct. Carry out socialization so that everyone is able to manage the diversity of regional cultures. The art of Tari Buku must be preserved and also preserved, not only Tari Buku but all cultures which are inheritances that have a lot of cultural diversity that is spread across various tribes and islands. As the nation's next generation who has a duty to preserve.

\subsection{Performance Form}

The form of dance performance is a form of form of all elements in the dance that form a unity, so that the dance presentation will be more interesting when viewed as a whole from the elements of the dance. A dance performance will be valued and appreciated when presented in a physical form. The physical form displayed by the dancers through movement. a form of appearance of other physical elements that support dance offerings that can give expression in a dance performance. Dance performances in it are supported by dancers as the main support. In addition to dancers, the presence of elements such as a place for performance, make-up, clothing, dance music and other dance equipment also gives an attraction and a sense of stability in the dance presented.

Performing art forms as works of artists are born as expressions through elements of dance formation. The form of sound is in the form of music that can be heard by the ear senses, while the form of clothing and make-up can be seen by the sense of sight. The form of the Tari Buku performance from North Nias can be seen through the sequence of performances and the supporting aspects of the performance. The main aspects in the form of the North Nias Tari Buku performance are divided into 5, namely (1) Movement (2) Accompaniment (3) Property (4) Make-up (5) Dressmaking. 


\section{References}

Adlin, D. (2020). Aesthetic Concept - Choreography of Piso Surit Dance in Karo Community. Budapest International Research and Critics in Linguistics and Education (BirLE) Journal Vol 3 (1): 172-182.

Ahmad, Ali Haidlor. 2010. Kearifan Lokal sebagai Landasan Pembangunan Bangsa. Harmoni Jurnal Multikultural \& Multireligius. 34(IX). Hlm. 5-8.

Alwasilah, A Chaidar.2006. Pokoknya Sunda (Interpretasi untuk Aksi). Bandung Kiblat

Erlinda, 2004, "Tari Minangkabau Dalam Dimensi Sosiokultural (Tradisi Dan Perkembangan)", dalam EKSPRESI: Jurnal Institut Seni Indonesia Yogyakarta, Yogyakarta: ISI Yogyakarta, vol 10. Tahun 4.2004.

Febrianto, E.G., Djono, and Sudiyanto. (2020). The Existence of Jaranan Pogogan in Sugihwaras, Prambon, Nganjuk, Indonesia. Budapest International Research and Critics in Linguistics and Education (BirLE) Journal Vol 3 (2): 773-776.

Harymawan, RMA. 1993. Dramaturgi. Bandung: Rosda Karya

Hamid, Abdul. (2014). Teori Belajar dan Pembelajaran, Medan: Program Pascasarjana Universitas Negeri Medan.

Jaeni. 2017. Nilai-nilai pengetahuan Lokal Pembentuk Karakter Bangsa Dalam Sandiwara Cirebon, Jawa Barat. Jurnal Seni Budaya Mudra Vol.32 p 1-8

Jazuli, M. 1994. Telaah Teori Seni Tari. Semarang: IKIP Semarang Press

Jazuli, M. 2001. Paradigma Seni Pertunjukan Sebuah Wacana Seni Tari, Wayang, dan Seniman. Yogyakarta: Lentera

Mulyanto . 2016. Belajar Pembelajaran. Bandung: Universitas Pendidikan Indonesia

Nugrahaningsih, R.H.D. (2020). Manduda Dance in Simalungun Community Dancing Style in a Contextual Perspective. Budapest International Research and Critics in Linguistics and Education (BirLE) Journal Vol 3 (1): 164-171.

Nurwani, et.al. (2020). The Creativity Of Society Making Ritual Becomes Show Art: Transformation Of Ratok Bawak Meaning on Minangkabau Society, Indonesia.

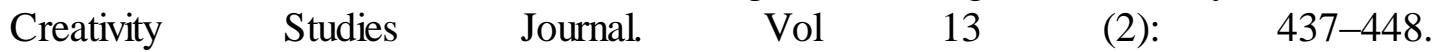
https://doi.org/10.3846/cs.2020.10326Rendra, 1983. Mempertimbangkan Tradisi. Jakarta: Gramedia

Rochmat, Nur, 2013, "Pewarisan tari Topeng Gaya Dermayon: Studi Kasus Gaya Rasinah", dalam Jurnal resital, Bandung: STSI Bandung, vol 14 no 1.

Rusyana, Yus, 2008, Seni Tradisi Dan Pengembangan Kreativitas, Bandung: Sunan Ambu Press

Soedarsono, (2012). "Revitalisasi Seni Rakyat dalam Rangka Pengembangan Kualitas Sumber Daya Masyarakat,'Jurnal Masyarakat Kebudayaan dan Politik, Volume 13, No. 1, hal. 63-67.

Soekanto, Soerjono. 2003.Sosiologi: Suatu Pengantar. Jakarta: Raja Grafindo Persada

Supanggah, Rahayu.2002. Etnomusikologi. Yayasan Betang Budaya

Supanggah, Rahayu. 2008.'Kesenimanan dalam Revitalisasi Kesenian", http://tradisilisan. blogspot.com/2008/04/kesenimanan-dalam-revitalisasi-kesenian.html (diunduh pada 10 Mei 2020). 